Jounal publiuho is licensed under a Creative Commons Attribution 4.0 International License, which permits unrestricted use, distribution, and reproduction in any medium, provided the original work is properly cited.

\title{
PEMANFAATAN DANA DESA UNTUK PENINGKATAN TARAF HIDUP MASYARAKAT PEDESAAN MELALUI PEMBERDAYAAN MASYARAKAT DESA
}

\author{
Oleh: \\ Rumsari Hadi Sumarto, Lukas Dwiantara ${ }^{2}$ \\ ${ }^{1}$ Dosen ASMI DESANTA Yogyakarta, ${ }^{2}$ Dosen ASMI Santa Maria Yogyakarta \\ rumsarimpa@gmail.com, lukasdwiantara@gmail.com
}

\begin{abstract}
Development is carried out to improve the standard of living of its citizens. Development is also carried out so that there is no disparity between villages and cities. The rapid development in urban areas which has triggered a wave of urbanization has made the villages increasingly marginalized. Urbanization flows are difficult to stem because the village mindset assumes that in the city they will get jobs so they can improve their standard of living. With this phenomenon, the Government rolled out the Village Fund Policy. The Village Fund Policy opens employment opportunities in the village so that the community can be empowered through development programs in the village. The purpose this paper is to describe the empowerment of rural communities through the Village Fund so that they can improve the living standard of rural communities. This paper uses a type of library research through documents analysis such as data contained in various media, books and other documents. The use of the Village Fund is significant to prevent the flow of urbanization. Opportunities for village communities to improve living standards were accommodated through community empowerment from the Village Fund.
\end{abstract}

\section{Keywords : Village Funds, Empowerment, Improvement of Life Level}

\section{PENDAHULUAN}

Pembangunan pada dasarnya dilaksanakan untuk merubah keadaan menjadi lebih baik. Oleh karena itu, setiap negara melaksanakan pembangunan agar kehidupan warganya meningkat menjadi lebih baik. Pembangunan yang dilaksanakan di Indonesia pada dasarnya untuk mencapai tujuan seperti yang tercantum dalam Alinea keempat Pembukaan UUD 1945. Alinea keempat Pembukaan UUD 1945 secara tegas menyatakan bahwa tujuan yang hendak dicapai oleh Pemerintah Republik Indonesia adalah untuk melindungi segenap Bangsa Indonesia dan seluruh tumpah darah Indonesia dan untuk memajukan kesejahteraan umum, mencerdaskan kehidupan bangsa, dan ikut melaksanakan ketertiban dunia yang berdasar kemerdekaan, perdamaian abadi dan keadilan sosial. Berkenaan dengan tujuan tersebut, berbagai kebijakan digulirkan untuk menjamin warganya berada dalam taraf hidup layak dan dapat merepresentasi sebagai warga yang tidak termarginalkan. Dengan demikian, Indonesia melaksanakan pembangunan di berbagai bidang agar mampu merubah keadaan menjadi lebih baik termasuk meningkatkan taraf hidup masyarakat dan menjadikan masyarakat Indonesia sejahtera.

Pembangunan juga dilaksanakan agar tidak terjadi ketimpangan antar wilayah termasuk antar desa dan kota. Pesatnya pembangunan di perkotaan seolah-olah menenggelamkan pembangunan desa yang sering diasumsi lambat dan kekurangan sumber daya. Masyarakat desa sering dideskripsikan sebagai masyarakat yang mayoritas hidup di bawah garis kemiskinan sehingga mereka meninggalkan desa untuk mencari kehidupan di kota. Mereka berasumsi bahwa kehidupan di kota lebih menjanjikan untuk dapat hidup layak. Dengan demikian, arus urbanisasi sulit dibendung karena mind set masyarakat desa telah terpola dengan asumsi bahwa di kota mereka akan mendapatkan pekerjaan dan akan dapat meningkatkan taraf hidup mereka. 
Vol.2 No.2. July 2019. pp.65-74. Copyright@2019 Journal PUBLICUHO. Faculty of Social and Political Sciences Halu Oleo University, Kendari, Southeast Sulawesi, Indonesia. ISSN: 2621-1351(electronic), 2685-0729 (print). Open Access at: http://ojs.uho.ac.id/index.php/PUBLICUHO

(C) Jounal publiuho is licensed under a Creative Commons Attribution 4.0 International License, which permits

Asumsi tersebut tidak sepenuhnya salah karena realita yang ada memang sulit bagi masyarakat desa untuk mendapatkan pekerjaan di desa sehingga mereka terkendala untuk memenuhi kebutuhan hidup mereka secara layak. Hal in ini disampaikan juga oleh Menteri Desa, Pembangunan Daerah Tertinggal dan Transmigrasi.

"Jakarta - Menteri Desa, Pembangunan Daerah Tertinggal, dan Transmigrasi Marwan Jafar membeberkan tantangan yang dihadapi dalam proses Desa Membangun Indonesia. Setidaknya ada tiga tantangan yang harus dihadapi. Tiga tantangan itu adalah desa belum menjadi daya tarik bagi penduduk, tingginya urbanisasi karena minimnya ketersediaan lapangan pekerjaan di desa dan masih tingginya jumlah keluarga petani miskin di desa. https:/news.detik.com/berita/3050182/ini-tigatantangan-dalam-program-desa-membangun-indonesia (diakses 7 Maret 2018)"

Daya tarik orang desa melakukan urban ke kota karena keterbatasan desa dalam menyediakan lapangan kerja memang tidak dapat dipungkiri. Gambaran pedesaan yang mayoritas dilingkupi dengan lahan pertanian ternyata belum mampu mengakomodir banyaknya permintaan tenaga kerja dari usia produktif di desa untuk berkerja di sektor pertanian. Kemudian keterbatasan sarana dan prasarana juga menghambat masyarakat desa untuk melakukan kegiatan sehingga menyebabkan masyarakat desa ingin berpindah ke kota. Realita banyaknya orang miskin di pedesaan dikarenakan mereka bukanlah mayoritas pemilik lahan pertanian dan mereka mengalami kendala dalam mencari tambahan penghasilan di luar pekerjaan sebagai 'buruh' tani di desa. Realita banyaknya orang miskin di pedesaan dapat dilihat pada paparan di bawah ini.

"Angka kemiskinan penduduk perdesaan jauh lebih besar dibandingkan dengan perkotaan. Data menunjukkan bahwa persentase penduduk miskin desa pada Maret 2017 masih mencapai 13,93 persen. Angka ini jauh lebih tinggi dibanding dengan persentase penduduk miskin perkotaan yang hanya 7,72 persen. Persentase penduduk desa juga di atas angka penduduk miskin nasional yang berada di level 10,64 persen pada Maret 2017. https://databoks.katadata.co.id/datapublish/2017/08/21/masyarakatmiskin-perdesaan-lebih-besar-dari-perkotaan (diakses 6 Maret 2018)"

Data tersebut menunjukkan bahwa penduduk miskin lebih banyak di pedesaan dari pada di perkotaan. Oleh karena itu, pembangunan di desa perlu menjadi prioritas agar mampu meningkatkan perfomance desa sehingga gelombang urbanisasi dapat diminimalisasi. Desa juga diharapkan dapat menjadi lahan pekerjaan bagi masyarakat desa sehingga mereka mendapat peluang bekerja untuk mendapatkan penghasilan yang layak dan hal ini berdampak pada taraf hidup mereka menjadi lebih meningkat dan mereka akan terlepas dari belenggu kemiskinan yang selama ini kerap menjadi permasalahan di desa.

Pemerintah memang tidak tinggal diam untuk permasalahan di desa. Berbagai kebijakan digulirkan untuk mengangkat desa dari keterpurukan dan keterbelakangan. Sudah selayaknya pemerintah memang lebih memfokuskan pada pembangunan di desa agar masyarakat desa dapat merasakan dampak positif dari pembangunan.

Adapun penelitian terdahulu yang berkaitan dengan dana desa diantaranya adalah penelitian dari Chasanah, Slamet Rosyadi, dan Denok Kurniasih (2017) dengan judul Implementasi Kebijakan Dana Desa di Desa Gumelem Kulon Kabupaten Banjarnegara. Hasil penelitian mengemukakan bahwa implementasi Dana Desa belum berjalan secara optimal dikarenakan prioritas penggunaan Dana Desa yang seharusnya untuk pembangunan infrastruktur dan pemberdayaan masyarakat, baru fokus terhadap pembangunan infrastruktur saja. Penelitian lain dari Ruru, Lintje Kalangi, dan Novi S. Budiarso (2017) dengan judul Analisis Penerapan Alokasi Dana Desa (Add) Dalam Upaya Meningkatkan Pembangunan Desa (Studi Kasus Pada Desa Suwaan, Kecamatan Kalawat, Kabupaten Minahasa Utara). Hasil penelitian mengemukakan bahwa secara keseluruhan penerapan Alokasi Dana Desa sudah sesuai dengan tujuan pada umumnya yaitu untuk meningkatkan pembangunan baik fisik 
Vol.2 No.2. July 2019. pp.65-74. Copyright@2019 Journal PUBLICUHO Faculty of Social and Political Sciences Halu Oleo University, Kendari, Southeast Sulawesi, Indonesia. ISSN: 2621-1351(electronic), 2685-0729 (print) Open Access at:

http://ojs.uho.ac.id/index.php/PUBLICUHO

Jounal publiuho is licensed under a Creative Commons Attribution 4.0 International License, which permits unrestricted use, distribution, and reproduction in any medium, provided the original work is properly cited.

maupun nonfisik. Sedang hasil penelitian dari Sofianto (2017) dengan judul Kontribusi Dana Desa terhadap Pembangunan dan Pemberdayaan Masyarakat di Kebumen dan Pekalongan mengemukakan bahwa pada umumnya masyarakat dan pemerintah desa merasa cukup terbantu karena dana desa memberikan sumbangan yang cukup berarti bagi pembangunan desa. Perbedaan dengan penelitian terdahulu pada makalah ini adalah bahwa alokasi Dana Desa lebih difokuskan pada alokasi dana desa yang berdampak pada peningkatan taraf hidup masyarakat pedesaan melalui pemberdayaan masyarakat desa dan bukan berfokus pada akuntabilitas penggunaan dana desa dan pembangunan infrastruktur.

Adapun tujuan dari penulisan makalah ini adalah mendeskripsikan pemberdayaan masyarakat desa melalui Alokasi Dana Desa sehingga mampu meningkatkan taraf hidup masyarakat pedesaan.

\section{TINJAUUAN TEORITIS}

Desa adalah wilayah dengan batas-batas tertentu sebagai kesatuan masyarakat hukum (adat) yang berhak mengatur dan mengurus urusan masyarakat setempat berdasar asal usulnya (Nurcholis 2011: 1). Ditambahkan juga oleh Nurcholis bahwa kedudukan desa sangat penting baik sebagai alat untuk mencapai tujuan pembangunan nasional ataupun sebagai lembaga yang memperkuat struktur pemerintahan negara Indonesia (2011: 2). Dengan demikian, desa merupakan wilayah pada tingkat paling bawah yang dapat membantu pemerintah dalam merealisasikan tujuan pembangunan dan memperkuat struktur pemerintahan.

Namun demikian, sebagai media perpanjangan dari tujuan pembangunan nasional, dalam realitanya masyarakat yang hidup dalam lingkaran kemiskinan banyak terjadi di desa-desa. Adapun ciri-ciri kemiskinan menurut Suharto diantaranya adalah ketidakmampuan memenuhi kebutuhan konsumsi dasar, ketiadaan akses terhadap kebutuhan hidup dasar lainnya (kesehatan, pendidikan, sanitasi, air bersih, dan transportasi), ketiadaan jaminan masa depan, rendahnya kualitas sumber daya manusia, dan ketiadaan akses terhadap lapangan kerja dan mata pencaharian yang berkesinambungan (2014: 132). Ketidakmampuan dan ketiadaan akses terhadap lapangan kerja memang banyak terjadi di desa-desa. Lapangan pekerjaan di desa memang tidak seluas lapangan kerja yang ada di kota. Tidak tersedianya lapangan kerja yang luas bagi masyarakat desa mengakibatkan gelombang arus urbanisasi semakin meningkat ke kota. Tidak adanya jaminan akan masa depan masyarakat desa menjadikan alasan bagi masyarakat untuk melakukan urbanisasi ke kota. Dengan demikian, fenomena urbanisasi memang merupakan alasan kuat bagi masyarakat desa karena ketiadaan akses akan lapangan kerja walaupun mayoritas dari masyarakat desa kurang memiliki kompetensi yang memadai untuk bersaing mendapatkan peluang kerja di kota.

Dengan adanya fenomena tersebut, pembangunan mutlak harus dilakukan di desa untuk memutus rantai kemiskinan dan keterbelakangan di desa. Menurut Mardikanto dan Purwoko Soebiyanto, pembangunan adalah upaya untuk tercapainya perbaikan kesejahteraan hidup bagi setiap individu maupun masyarakat luas (2017: 2). Sedang menurut Riyadi, pembangunan adalah suatu usaha atau proses perubahan, demi tercapainya tingkat kesejahteraan atau mutu hidup suatu masyarakat serta individu-individu di dalamnya yang berkehendak dan melaksanakan pembangunan itu (Mardikanto dan Purwoko Soebiyanto 2017: 3). Pembangunan pada hakekatnya merupakan suatu kondisi untuk mengubah keadaan menjadi lebih baik. Negara di penjuru dunia manapun melakukan pembangunan agar negaranya dapat berkembang ke arah yang lebih baik, lebih maju dan modern. Indonesia pun melaksanakan pembangunan untuk menjadikan negara ini lebih baik dan lebih maju dan terutama juga untuk meningkatkan kesejahteraan masyarakatnya.

Korten menyatakan bahwa konsep pembangunan berpusat pada rakyat memandang inisiatif dan kreatif dari rakyat sebagai sumber daya pembangunan yang utama dan memandang kesejahteraan material dan spiritual mereka sebagai tujuan yang ingin dicapai oleh proses pembangunan (Mardikanto dan Purwoko Soebiyanto 2017: 56). Pembangunan merupakan suatu proses ke arah perubahan yang lebih baik dengan memposisikan masyarakat sebagai sumber daya pembangunan sehingga rakyat dapat memperbaiki kesejahteraan hidupnya. Dengan adanya pembangunan terutama pembangunan di pedesaan, maka lapangan kerja akan tercipta 
Vol.2 No.2. July 2019. pp.65-74. Copyright@2019 Journal PUBLICUHO. Faculty of Social and Political Sciences Halu Oleo University, Kendari, Southeast Sulawesi, Indonesia. ISSN: 2621-1351(electronic), 2685-0729 (print). Open Access at: http://ojs.uho.ac.id/index.php/PUBLICUHO

Jounal publiuho is licensed under a Creative Commons Attribution 4.0 International License, which permits unrestricted use, distribution, and reproduction in any medium, provided the original work is properly cited.

sehingga masyarakat desa tidak harus mencari peluang kerja di tempat lain. Dengan demikian, akses untuk mencapai kesejahteraan dan meningkatkan kualitas hidup masyarakat pedesaan dapat tercapai.

Untuk pembangunan di pedesaan, tidak sedikit usaha pemerintah untuk fokus pada peningkatan kesejahteraan masyarakat pedesaan di Indonesia dan melepaskan masyarakat pedesaan tersebut dari belenggu kemiskinan. Berbagai kebijakan digulirkan untuk mengeksekusi program pengentasan kemiskinan dan meminimalisir ketidakmerataan yang terjadi di Indonesia. Menurut Winarno, kebijakan publik pada dasarnya merupakan arah tindakan yang dilakukan pemerintah, area studi meliputi segala tindakan yang dilakukan oleh pemerintah dan mempunyai pengaruh terhadap kepentingan masyarakat secara luas (2008: 30). Kebijakan mengentaskan masyarakat dari lingkaran kemiskinan terutama masyarakat pedesaan perlu menjadi prioritas karena berpengaruh signifikan terhadap kepentingan masyarakat luas khususnya masyarakat pedesaan dalam meningkatkan taraf hidupnya. Implementasi kebijakan terhadap pengentasan kemiskinan masyarakat di pedesaan merupakan realisasi dari prinsip keadilan di mana hidup sejahtera adalah hak setiap warga negara.

Menurut Little, keadilan adalah tentang melindungi orang dan harta benda, menegakkan kontrak, dan mendukung konvensi sosial yang penting (2004: 133). Konsep keadilan secara tradisional berkaitan dengan hak dan kewajiban (Little 2004: 59). Kemudian John Rawls juga mengemukakan hasil pemikiran yang tertuang dalam istilahnya yang terkenal yaitu "The Principles of Justice" (Prinsip-Prinsip Keadilan). Prinsip tersebut diantaranya mengatakan bahwa: (1) setiap orang memiliki hak yang sama terhadap kebebasan dasar yang paling luas dengan sistem kebebasan yang sama untuk semua orang, (2) ketidaksetaraan sosial dan ekonomi harus diatur sedemikian rupa sehingga diharapkan dapat memberi keuntungan terbesar bagi semua orang dalam prinsip kesetaraan yang adil, dan melekat pada semua kantor dan jabatan terbuka bagi semua orang (Little 2004: 56 - 57). Dengan demikian, masyarakat desa yang dianalogikan sebagai masyarakat yang tidak diuntungkan atau sering diidentikkan dengan kaum terpinggirkan memiliki hak untuk dilindungi dan hak untuk hidup layak. Prinsip keadilan di sini dalam arti masyarakat miskin di desa berhak untuk hidup sejahtera. Oleh karena itu, negara seyogyanya hadir untuk mengentaskan masyarakat desa dari belenggu kemiskinan sehingga mereka memiliki kesempatan yang sama untuk hidup sejahtera. Pembangunan di pedesaan kiranya perlu menjadi fokus pemerintah agar tidak terjadi ketimpangan antara desa dan kota sehingga desa dapat menjadi daya tarik bagi masyarakat desa sendiri untuk berkarya membangun desanya dan tidak melakukan urbanisasi ke kota yang diasumsikan memiliki prospek hidup yang lebih menjanjikan.

Dalam pembangunan, masyarakat juga perlu diberdayakan sehingga masyarakat menjadi bagian dari proses perubahan tersebut dan bukan sebagai obyek pembangunan. Dikatakan oleh Mardikanto dan Purwoko Soebiyanto bahwa inti pembangunan berpusat pada rakyat adalah pemberdayaan (empowerment) yang mengarah pada kemandirian masyarakat (2017: 19). Menurut Mas'oed, pemberdayaan diartikan sebagai upaya untuk memberikan daya (empowerment) atau penguatan (Strenthening) kepada masyarakat (Mardikanto dan Purwoko Soebiyanto 2017: 26). Sedangkan menurut Mardikanto dan Purwoko Soebiyanto, memberdayakan masyarakat adalah upaya untuk meningkatkan harkat dan martabat lapisan masyarakat yang dalam kondisi sekarang tidak mampu untuk melepaskan diri dari perangkap kemiskinan dan keterbelakangan. Dengan perkataan lain memberdayakan adalah memampukan dan memandirikan masyarakat (2017: 40). Ditambahkan oleh Suharto bahwa pemberdayaan menunjuk pada kemampuan orang, khususnya kelompok rentan dan lemah sehingga mereka memiliki kekuatan atau kemampuan dalam memenuhi kebutuhan dasarnya sehingga mereka memiliki kebebasan, dan menjangkau sumber-sumber produktif yang memungkinkan mereka dapat meningkatkan pendapatannya dan memperoleh barang dan jasa yang mereka perlukan serta berpartisipasi dalam proses pembangunan (2014: 58). Pemberdayaan untuk masyarakat pedesaan dapat memampukan masyarakat desa sebagai pihak yang lemah dan berada pada kondisi ketidakberdayaan karena terbelenggu dalam rantai kemiskinan menjadi sosok yang mampu memenuhi kebutuhan dasar masyarakat pedesaan dan 
Vol.2 No.2. July 2019. pp.65-74. Copyright@2019 Journal PUBLICUHO Faculty of Social and Political Sciences Halu Oleo University, Kendari, Southeast Sulawesi, Indonesia. ISSN: 2621-1351(electronic), 2685-0729 (print) Open Access at:

http://ojs.uho.ac.id/index.php/PUBLICUHO

Jounal publiuho is licensed under a Creative Commons Attribution 4.0 International License, which permits unrestricted use, distribution, and reproduction in any medium, provided the original work is properly cited.

mampu mengakses sumber-sumber produktif sehingga mampu meningkatkan pendapatan masyarakat pedesaan yang signifikan dapat meningkatkan taraf hidup masyarakat pedesaan.

Dalam UU No. 6 Tahun 2014 tentang Desa, disebutkan bahwa pemberdayaan masyarakat desa didefinisikan sebagai upaya mengembangkan kemandirian dan kesejahteraan masyarakat dengan meningkatkan pengetahuan, sikap, keterampilan, perilaku, kemampuan, kesadaran, serta memanfaatkan sumber daya melalui penetapan kebijakan, program, kegiatan, dan pendampingan yang sesuai dengan esensi masalah dan prioritas kebutuhan masyarakat desa. Adapun tujuan pemberdayaan masyarakat desa, sebagaimana dimaksud dalam PP No. 43 Tahun 2014 tentang Peraturan Pelaksanaan UU No. 6 Tentang Desa, adalah memampukan Desa dalam melakukan aksi bersama sebagai suatu kesatuan tata kelola Pemerintahan Desa, kesatuan tata kelola lembaga kemasyarakatan Desa dan lembaga adat, serta kesatuan tata ekonomi dan lingkungan.

Pada prinsipnya, pemberdayaan masyarakat (people empowerment) dapat juga dimaknai sebagai suatu upaya menguatkan power (daya) atau empowering dari golongan masyarakat yang powerless (tidak berdaya) yaitu biasanya mereka yang sedang tergolong ke dalam masyarakat marjinal (Sunaryo 2013: 216). Masyarakat pedesaan perlu diberdayakan agar masyarakat dapat mengembangkan kemandirian, mampu meningkatkan kualitas dirinya untuk meraih kehidupan yang lebih baik. Dengan adanya peningkatan kualitas diri masyarakat desa, maka masyarakat pedesaan mampu membangun wilayahnya untuk menjadi lebih baik dan mampu menjadi tuan rumah di wilayahnya sendiri dengan menciptakan peluang-peluang kerja yang dapat diakses oleh masyaraka pedesaan sehingga tidak perlu mencari peluang di wilayah lain.

Adapun unsur utama dari proses pemberdayaan masyarakat adalah pemberian wewenang dan pengembangan kapasitas kepada masyarakat (Soetomo 2013: 88). Dalam konteks ini partisipasi masyarakat menjadi sangat penting. Melalui partisipasi, kemampuan masyarakat dan perjuangan mereka untuk membangkitkan dan menopang pertumbuhan kolektif menjadi kuat (Mardikanto dan Purwoko Soebiyanto 2017: 19). Oleh karena itu, dalam pemberdayaan, partisipasi menjadi vital karena adanya akses untuk memberdayakan dirinya dalam meraih peluang-peluang untuk meningkatkan harapan hidupnya menjadi lebih baik. Masyarakat desa harus dijadikan subyek pembangunan sehingga pembangunan yang dilaksanakan merupakan realisasi dari ekspetasi masyarakat desa sendiri yang sangat paham bagaimana mereka harus membangun wilayahnya dengan situasi dan kondisi yang ada di pedesaan tempat masyarakat berada.

\section{METODE PENELITIAN}

Tulisan menggunakan jenis penelitian perpustakaan. Menurut Pasolong, penelitian perpustakaan adalah penyelidikan yang bertujuan untuk mengumpulkan data dan informasi yang terdapat di ruang perpustakaan, seperti buku, majalah, dokumen, catatan kisah-kisah sejarah dan lainnya (2013: 69). Dokumentasi seperti informasi atau data-data yang terdapat di media baik media online maupun media cetak, buku-buku dan dokumen lainnya dianalisis dan digunakan dalam penulisan ini.

Teknik pengumpulan data dilakukan dengan metode dokumentasi. Menurut Creswell, rekaman atau catatan haruslah merefleksikan informasi mengenai dokumen tersebut atau materi lain serta gagasan-gagasan inti dalam dokumen tersebut (2014: 274). Pengumpulan data melalui media cetak baik elektronik maupun cetak, jurnal dan buku-buku dilakukan penulis untuk melengkapi data dalam penulisan makalah ini. Selanjutnya teknik analisis data di gunakan analisis data deskriptif dengan menggunakan pendekatan kualitatif lalu di verifikasi dan mengambil kesimpulan. 
Vol.2 No.2. July 2019. pp.65-74. Copyright@2019 Journal PUBLICUHO. Faculty of Social and Political Sciences Halu Oleo University, Kendari, Southeast Sulawesi, Indonesia. ISSN: 2621-1351(electronic), 2685-0729 (print). Open Access at: http://ojs.uho.ac.id/index.php/PUBLICUHO

Jounal publiuho is licensed under a Creative Commons Attribution 4.0 International License, which permits unrestricted use, distribution, and reproduction in any medium, provided the original work is properly cited.

\section{PEMBAHASAN}

Salah satu kebijakan di era pemerintahan saat ini adalah fokus juga pada peningkatan pembangunan di desa. Desa tidak boleh diabaikan karena sebagian besar masyarakat Indonesia hidup di pedesaan. Kebijakan yang diluncurkan oleh pemerintah adalah Dana Desa.

"Dana Desa adalah dana yang bersumber dari Anggaran Pendapatan dan Belanja Negara yang diperuntukkan bagi Desa dan Desa Adat yang ditransfer melalui Anggaran Pendapatan dan Belanja Daerah kabupaten/kota dan digunakan untuk membiayai penyelenggaran pemerintahan, pembangunan, serta pemberdayaan masyarakat, dan kemasyarakatan. https://simperdededemak.wordpress.com/anggaran-dd-2 (diakses 7 Maret 2018)"

Adapun alokasi Dana Desa yang direalisasikan melalui pembangunan di pedesaan telah menunjukkan dampak positifnya.

Program dana desa memiliki dampak sangat besar terhadap pembangunan di desa. Untuk pertama kali, Indonesia mampu membangun sepanjang 121.709 kilometer $(\mathrm{km})$, jembatan $1.960 \mathrm{~km}$, air bersih sebanyak 32.711 unit, Polindes 6.041 unit, saluran irigasi 41.739 unit, drainase 590.371 unit, dan tambatan perahu 5.116 unit. Selain itu, Badan Usaha Milik Desa (BUMDes) 21.811 unit, embung 2.047 unit, MCK 82.356 unit, pasar desa 5.220 unit, bangunan pendidikan anak usia dini (PAUD) 21.357 unit, posyandu 13.973 unit, sumur 45.865 unit, penahan tanah 291.393 unit, dan sarana olahraga 2.366 unit. "Itu juga ada unsur swadaya masyarakat desa. Karena masyarakat desa kalau dibikinkan jalan, irigasi, dan lainnya, masyarakat desa kan senang," ungkap Eko. http://bisnis.liputan6.com/read/3151352/dana-desa-2018-mampu-serap-57-juta-tenaga-kerja （diakses 7 Maret 2018)

Dengan demikian, Dana Desa yang diberikan kepada masyarakat pedesaan dapat dimanfaatkan untuk pembangunan. Masyarakat desa tentu saja dapat merasakan dampak positifnya dengan adanya Dana Desa. Sarana dan prasarana yang sebelumnya sulit untuk direalisasi karena minimnya anggaran untuk pembangunan jalan dan jembatan, sarana air bersih dan sumur, pasar, sarana olah raga, sarana pendidikan dan pembangunan sarana lainnya, maka dengan adanya Dana Desa sarana dan prasarana tersebut dapat diakses oleh masyarakat desa. Sarana dan prasarana tersebut sangat dibutuhkan oleh masyarakat desa. Tanpa adanya Dana Desa, maka lokasi yang sulit terjangkau karena infrastruktur seperti jalan dan jembatan yang belum representatif akan menghambat akses masyarakat desa untuk melakukan aktivitas produktif.

Berkenaan dengan pemberdayaan, kebijakan Dana Desa yang digulirkan pemerintah memfokuskan juga pada pemberdayaan masyarakat desa.

"Sesuai dengan amanat Undang-Undang Nomor 6 Tahun 2014 tentang Desa, Pemerintah mengalokasikan Dana Desa, melalui mekanisme transfer kepada Kabupaten/Kota. Berdasarkan alokasi Dana tersebut, maka tiap Kabupaten/Kota mengalokasikannya ke pada setiap desa berdasarkan jumlah desa dengan memperhatikan jumlah penduduk (30\%), luas wilayah (20\%), dan angka kemiskinan (50\%). Berdasarkan Peraturan Pemerintah No. 60 Tahun 2014 tentang Dana Desa Yang Bersumber dari APBN, dengan luasnya lingkup kewenangan Desa dan dalam rangka mengoptimalkan penggunaan Dana Desa, maka penggunaan Dana Desa diprioritaskan untuk membiayai pembangunan dan pemberdayaan masyarakat Desa. Penetapan prioritas penggunaan dana tersebut tetap sejalan dengan kewenangan yang menjadi tanggungjawab Desa. https://simperdededemak.wordpress.com/anggaran-dd-2 "(diakses 7 Maret 2018)

Dana Desa sangat bermanfaat untuk masyarakat desa di mana sebelum adanya dana desa, pembangunan desa mengalami kendala karena minimnya alokasi anggaran untuk pembangunan dan pemberdayaan masyarakat di 
Vol.2 No.2. July 2019. pp.65-74. Copyright@2019 Journal PUBLICUHO Faculty of Social and Political Sciences Halu Oleo University, Kendari, Southeast Sulawesi, Indonesia. ISSN: 2621-1351(electronic), 2685-0729 (print) Open Access at:

http://ojs.uho.ac.id/index.php/PUBLICUHO

Jounal publiuho is licensed under a Creative Commons Attribution 4.0 International License, which permits unrestricted use, distribution, and reproduction in any medium, provided the original work is properly cited.

pedesaaan. Alokasi Dana Desa untuk pemberdayaan sangat vital karena melalui pemberdayaan, kemampuan masyarakat desa dapat ditingkatkan sehingga mampu merepresentasikan dirinya sebagai sosok yang mandiri dan berdaya. Hal ini juga dikemukakan dalam Buku Pintar Dana Desa.

Di dalam Buku Pintar Dana Desa dijelaskan bahwa hal yang penting yang dapat diterapkan dalam pengelolaan Dana Desa dengan melibatkan masyarakat adalah perlunya melakukan kegiatan dengan pola swakelola, menggunakan tenaga kerja setempat, dan memanfaatkan bahan baku lokal yang ada di desa. Dengan pola swakelola, berarti diupayakan perencanaan dan pelaksanaan kegiatan tersebut dilakukan secara mandiri oleh Desa, sehingga uang yang digunakan untuk pembangunan tersebut tidak akan mengalir keluar desa. Dengan menggunakan tenaga kerja setempat, diharapkan pelaksanaan kegiatan tersebut bisa menyerap tenaga kerja dan memberikan pendapatan bagi mereka yang bekerja. Sementara penggunaan bahan baku lokal diharapkan akan memberikan penghasilan kepada masyarakat yang memiliki bahan baku tersebut. (www.djpk.kemenkeu.go.id) (diakses 6 Maret 2018)

Dengan adanya Dana Desa, pembangunan dan pemberdayaan masyarakat di pedesaan berkorelasi positif untuk membuat wajah pedesaan menjadi lebih baik. Warga di pedesaan pun diberdayakan dengan swakelola sehingga masyarakat desa lah yang mendapat manfaat dari dana desa tersebut. Penyerapan tenaga kerja akan semakin terbuka sehingga masyarakat desa tidak perlu lagi mencari peluang kerja di kota. Dengan terbukanya kesempatan kerja di desa, terbuka juga harapan untuk meningkatkan taraf hidup masyarakat desa sehingga tidak terbelenggu dalam rantai kemiskinan.

Menurut Buku Pintar Dana Desa, hasil evaluasi penggunaan Dana Desa selama dua tahun terakhir juga menunjukkan bahwa Dana Desa telah berhasil meningkatkan kualitas hidup masyarakat desa yang ditunjukkan, antara lain dengan menurunnya rasio ketimpangan perdesaan dari 0,34 pada tahun 2014 menjadi 0,32 di tahun 2017. Menurunnya jumlah penduduk miskin perdesaan dari 17,7 juta tahun 2014 menjadi 17,1 juta tahun 2017 dan, adanya penurunan persentase penduduk miskin perdesaan dari 14,09\% pada tahun 2015 menjadi $13,93 \%$ di tahun 2017. Pencapaian ini akan dapat ditingkatkan lagi di tahun-tahun mendatang dengan pengelolaan Dana Desa yang baik (www.djpk.kemenkeu.go.id) (diakses 6 Maret 2018).

Permasalahan yang sering mengemuka selama ini mengenai ketimpangan antara kota dan desa adalah mengenai peluang mencari kerja hingga berdampak pada minimnya penghasilan dan berdampak lanjut pada tingginya angka kemiskinan di pedesaan. Dengan digulirkannya kebijakan Dana Desa, pada tahun 2017 persentase penduduk miskin di pedesaan turun menjadi 13,93\%. Dengan demikian, kebijakan alokasi Dana Desa signifikan untuk mengatasi permasalahan di desa yang selama beberapa dekade sulit untuk melaksanakan pembangunan di pedesaan dan terkendala untuk mencapai kesejahteraan masyarakat desa. Hal ini juga disampaikan oleh Sri Mulyani.

"Liputan6.com, Jakarta - Menteri Keuangan (Menkeu) Sri Mulyani Indrawati menjelaskan instruksi Presiden Joko Widodo (Jokowi) untuk menggenjot proyek padat karya besar-besaran melalui dana desa di tahun depan. Tujuannya untuk mengerek daya beli masyarakat serta menciptakan lapangan kerja sehingga mengurangi pengangguran dan jumlah orang miskin. Untuk periode 2018, kata Sri Mulyani, alokasi dana desa sebesar Rp 60 triliun akan difokuskan kepada desa-desa miskin dan yang memiliki populasi orang miskin lebih banyak. http://bisnis.liputan6.com/read/3147540/gebrakanjokowi-genjot-penggunaan-dana-desa-rp-60-triliun "(diakses 7 Maret 2018).

Pernyataan Sri Mulyani sebagai Menteri Keuangan mengisyaratkan bahwa pada tahun 2018 ini, mega proyek padat karya di desa akan memberi peluang kerja bagi masyarakat di pedesaan. Dengan adanya peluang kerja tersebut, kesempatan mencari kerja di desa lebih terbuka dan hal ini akan meminimalisir keinginan masyarakat desa mencari kerja di luar. Dengan adanya kesempatan kerja di desa, masyarakat desa akan mendapat income sehingga mampu memenuhi kebutuhan hidupnya. Dengan meningkatnya kesejahteraan masyarakat di pedesaan, secara otomatis akan mengurangi angka kemiskinan yang ada di pedesaan. Pernyataan Sri Mulyani kemudian juga dikuatkan melalui Keputusan Bersama 4 Menteri. 
"Keputusan Bersama (SKB) 4 Menteri yakni Menteri PPN/Bappenas, Menteri Keuangan, Menteri Dalam Negeri, dan Menteri Desa Pembangunan Daerah Tertinggal dan Transmigrasi pada 18 Desember 2017 lalu memandatkan, bahwa Dana Desa digunakan untuk Padat Karya Tunai di Desa. Padat Karya Tunai di Desa (PKTD) merupakan kegiatan pemberdayaan masyarakat desa, khususnya yang miskin dan marginal yang bersifat produktif, dengan mengutamakan pemanfaatan sumber daya, tenaga kerja, dan teknologi lokal untuk memberikan tambahan upah/pendapatan, meningkatkan daya beli, mengurangi kemiskinan, dan sekaligus mendukung penurunan angka stunting. Ini adalah program arahan langsung dari presiden, yang dilaksanakan untuk seluruh desa di Indonesia. https://nasional.tempo.co/read/1107128/penggunaandana-desa-2018-untuk-program-padat-karya-tunai-di-desa "(Diakses 7 November 2018).

Dengan adanya program Padat Karya Tunai di Desa (PKTD), pemberdayaan masyarakat dapat dioptimalkan melalui pemanfaatan sumber daya dan tenaga kerja lokal di desa. Dengan pemanfaatan tenaga kerja lokal, maka akan berkorelasi terhadap tambahan pendapatan atau penghasilan. Dengan adanya tambahan pendapatan, maka akan dapat meningkatkan taraf hidup masyarakat desa ke arah yang lebih baik.

Adapun program padat karya salah satunya berada di Desa Kersanagara, Kecamatan Cibeureum, Kota Tasikmalaya.

"Presiden Joko Widodo (Jokowi) beserta Menteri Pekerjaan Umum dan Perumahan Rakyat (PUPR) Basuki Hadimuljono dan Gubernur Jawa Barat Ahmad Heryawan meninjau lokasi program Padat Karya Tunai di Desa Kersanagara, Kecamatan Cibeureum, Kota Tasikmalaya, pada Selasa 16 Januari 2018. Kunjungan tersebut sekaligus menandai dimulainya program Padat Karya Tunai melalui Program Percepatan Peningkatan Tata Guna Air Irigasi (P3-TGAI) di 169 lokasi yang berada di Kabupaten dan Kota Tasikmalaya. Melalui P3-TGAI, Kementerian PUPR berupaya untuk meningkatkan partisipasi petani dalam perbaikan dan peningkatan jaringan irigasi. http://bisnis.liputan6.com/read/3231552/alasan-jokowi-keluarkan-program-padat-karya-tunai (diakses 7 Maret 2018)"

Dengan demikian, pemanfaatan Dana Desa melalui proyek padat karya di Desa Kersanagara melalui program Percepatan Peningkatan Tata Guna Air Irigasi dapat membantu masyarakat tidak hanya dari sisi perolehan pendapatan, tetapi proyek tersebut juga bermanfaat bagi masyarakat terutama yang hidup di sektor pertanian. Proyek-proyek padat karya lainnya juga dapat menjadi solusi untuk pembangunan di desa sesuai dengan karakteristik pedesaan sehingga pemanfaatan pembangunan di pedesaan berdampak positif bagi masyarakat desa dan perkembangan desa. Proyek padat karya berdampak positif pada terbukanya ekspetasi masyarakat desa untuk meningkatkan taraf hidupnya melalui pendapatan yang diperoleh dari proyek padat karya.

Dampak dari kebijakan Dana Desa akan menjadikan situasi dan kondisi pedesaan berubah dari keterbelakangan dan keterpurukan menjadi wilayah yang berkembang dengan peningkatan infrastruktur di pedesaan. Kualitas SDM dan kualitas hidup masyarakat desa juga semakin meningkat melalui pemberdayaan masyarakat dari kebijakan Dana Desa. Pembangunan secara umum memiliki tujuan untuk merubah keadaan menjadi lebih baik. Setiap negara melakukan pembangunan agar kehidupan masyarakat meningkat menjadi lebih baik atau tercapainya kesejahteraan masyarakat di negara tersebut. Untuk mencapai tujuan tersebut, pemerintah menggulirkan berbagai kebijakan untuk menuju kepada masyarakat yang sejahtera. Pembangunan digiatkan di berbagai sektor dan wilayah termasuk di pedesaan. Pesatnya pembangunan di perkotaan mengakibatkan semakin tingginya ketimpangan antara kota dan desa. Ketimpangan ini menjadikan masyarakat desa melakukan urbanisasi ke perkotaan yang diasumsikan dapat memperbaiki taraf hidup masyarakat desa. 
Vol.2 No.2. July 2019. pp.65-74. Copyright@2019 Journal PUBLICUHO Faculty of Social and Political Sciences Halu Oleo University, Kendari, Southeast Sulawesi, Indonesia. ISSN: 2621-1351(electronic), 2685-0729 (print) Open Access at:

http://ojs.uho.ac.id/index.php/PUBLICUHO

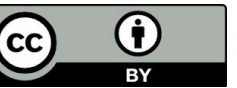

Jounal publiuho is licensed under a Creative Commons Attribution 4.0 International License, which permits unrestricted use, distribution, and reproduction in any medium, provided the original work is properly cited.

Dengan adanya fenomena tersebut, Pemerintah Indonesia menggulirkan kebijakan Dana Desa. Pemanfaatan Dana Desa siginifikan untuk mencegah arus urbanisasi dari masyarakat desa ke kota. Kebijakan Dana Desa membuka peluang kerja di desa sehingga masyarakat dapat diberdayakan di desa melalui program-program pembangunan yang dilakukan di desa. Proyek padat karya digulirkan selain untuk membuka kran pendapatan bagi masyarakat desa, proyek padat karya ini juga dilakukan sesuai kondisi dan tipikal daerah di pedesaan. Dengan demikian, alokasi dana yang digulirkan dapat tepat sasaran.

\section{KESIMPULAN}

Peluang masyarakat desa untuk meningkatkan taraf hidup dan meningkatkan derajad kehidupannya dapat terakomodasi melalui kebijakan Dana Desa. Oleh karena itu, seyogyanya Dana Desa tetap digulirkan hingga desa benar-benar menjadi wilayah yang mandiri, masyarakatnya berpendidikan dan sejahtera serta mampu mengangkat wajah desa menjadi lebih baik dengan program-program pembangunan yang telah dilakukan. Dengan adanya pemberdayaan masyarakat, maka masyarakat desa juga mampu meningkatkan harkat dan martabatnya sebagai manusia yang mandiri di mana dengan kondisi masa lalu yang lekat dengan kemiskinan menyebabkan jati diri masyarakat desa juga ikut tergerus dengan label kemiskinannya.

Sudah selayaknya bangsa Indonesia mendukung kebijakan Dana Desa agar pemerataan pembangunan dan kesejahteraan benar-benar dapat direalisasikan secara nyata dan dapat meminimalisir kesenjangan antara desa dan kota.

\section{DAFTAR PUSTAKA}

Ariyanti, Fiki. 2017. Gebrakan Jokowi Genjot Penggunaan Dana Desa Rp. 60 Triliun. http://bisnis.liputan6.com/read/3147540/gebrakan-jokowi-genjot-penggunaan-dana-desa-rp-60-triliun

Chasanah, Khuswatun, Slamet Rosyadi, dan Denok Kurniasih. 2017. Implementasi Kebijakan Dana Desa. IJPA The Indonesian Journal of Public Administration, Volume 3, Nomor 2 Desember 2017, p 12 - 32.

Creswell, John W. 2014. Research Design, Pendekatan Kualitatit, Kuantitatif dan Mixed. Yogyakarta: Pustaka Pelajar.

Databoks. 2017. Masyarakat Miskin Perdesaan Lebih Besar dari Perkotaan. https://ataboks.katadata.co.id/datapublish/2017/08/21/masyarakat-miskin-perdesaan-lebih-besar-dariperkotaan

Deny, Septian. 2018. Alasan Jokowi Keluarkan Program Padat Karya Tunai. http://bisnis.liputan6.com/read/3231552/alasan-jokowi-keluarkan-program-padat-karya-tunai

Kementrian Keuangan Republik Indonesia. 2017. Buku Pintar Dana Desa, Dana Desa untuk Kesejahteraan Rakyat. www.djpk.kemenkeu.go.id

Little, I.M.D. 2004. Ethics, Economics, and Politics, Principles of Public Policy. New York: Oxford University Press.

Mardikanto, Totok dan H. Purwoko Soebiyanto. 2017. Pemberdayaan Masyarakat dalam Perspektif Kebijakan Publik. Bandung: Alfabeta.

Nurcholis, Hanif. 2011. Pertumbuhan dan Penyelenggaraan Pemerintahan Desa. Jakarta: Erlangga.

Pasolong, Harbani. 2013. Metode Penelitian Administrasi Publik. Bandung: Alfabeta.

Peraturan Pemerintah No. 43 Tahun 2014 tentang Peraturan Pelaksanaan UU Nomor 6 Tahun 2014 tentang Desa

Ratya, Mega Putra. 2015. Ini Tiga Tantangan dalam Program Desa Membangun Indonesia. https://news.detik.com/berita/3050182/ini-tiga-tantangan-dalam-program-desa-membangun-indonesia

Ruru, Novianti, Lintje Kalangi, dan Novi S. Budiarso. 2017. Analisis Penerapan Alokasi Dana Desa (Add) Dalam Upaya Meningkatkan Pembangunan Desa (Studi Kasus Pada Desa Suwaan, Kecamatan Kalawat, Kabupaten Minahasa Utara), Jurnal Riset Akuntansi Going Concern 12 (1), p 83-90. 
Sistem Informasi Pencairan Dana Desa Kabupaten Demak. 2017. Apa Itu Dana Desa. https://simperdededemak.wordpress.com/anggaran-dd-2

Soetomo. 2013. Pemberdayaan Masyarakat, Mungkinkah Muncul Anti Tesisnya?. Yogyakarta: Pustaka Pelajar.

Sofianto, Arif Sofianto. 2017. Kontribusi Dana Desa terhadap Pembangunan dan Pemberdayaan Masyarakat di Kebumen dan Pekalongan. Matra Pembaruan l (1), p 23-32

Suharto, Edi. 2014. Membangun Masyarakat Memberdayakan Rakyat, Kajian Strategis Pembangunan Kesejahteraan sosial dan Pekerjaan Sosial. Bandung: Refika Aditama

Sunaryo, Bambang. 2013. Kebijakan Pembangunan Destinasi Pariwisata. Yogyakarta: Gava Media.

Tempo. 2018. Penggunaan Dana Desa 2018 untuk Program Padat Karya Tunai di Desa. https://nasional.tempo.co/read/1107128/penggunaan-dana-desa-2018-untuk-program-padat-karyatunai-di-desa

Undang-Undang Nomor 6 Tahun 2014 tentang Desa

Wicaksono, Pebrianto Eko. 2017. Dana Desa 2018 Mampu Serap 5,7 Juta Tenaga Kerja. http://bisnis.liputan6.com/read/3151352/dana-desa-2018-mampu-serap-57-juta-tenaga-kerja

Winarno, Budi. 2008. Kebijakan Publik, Teori dan Proses. Jakarta: Buku Kita 